\title{
Incorporation of Metals into Calcite in a Deep Anoxic Granite Aquifer
}

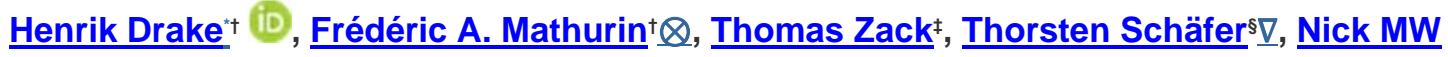 \\ Roberts" \\ + Department of Biology and Environmental Science, Linnaeus University, 39231 Kalmar, Sweden \\ ‡ Department of Earth Sciences, University of Gothenburg, 40530 Gothenburg, Sweden \\ $\S$ Karlsruhe Institute of Technology, Institute for Nuclear Waste Disposal, 76021 Karlsruhe, Germany \\ " NERC Isotope Geosciences Laboratory, British Geological Survey, Nottingham NG12 5GG, U.K. \\ $\perp$ Department of Geosciences, Swedish Museum of Natural History, 10405 Stockholm, Sweden \\ * Department of Geological Sciences, Stockholm University, Stockholm 106 91, Sweden
}

Environ. Sci. Technol., 2018, 52 (2), pp 493-502

DOI: 10.1021/acs.est.7b05258

\section{Abstract}

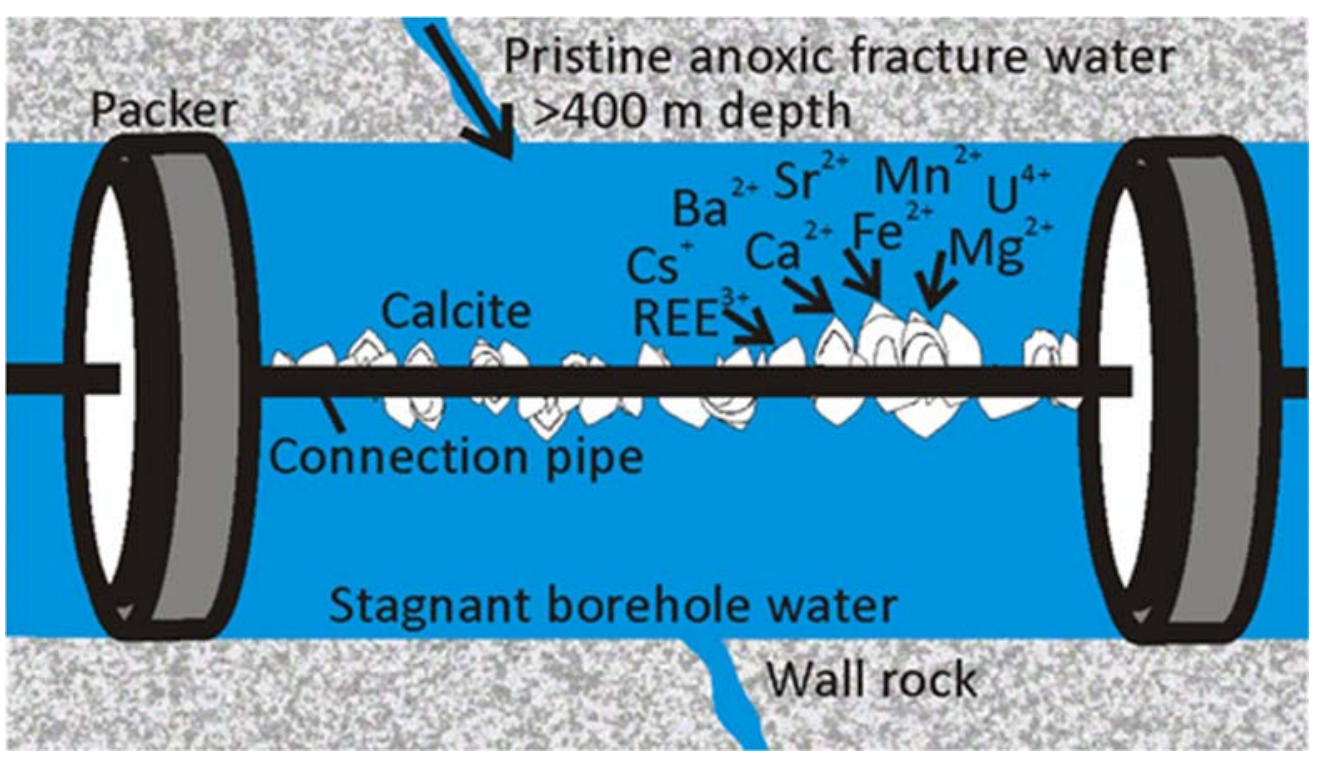

Understanding metal scavenging by calcite in deep aquifers in granite is of importance for deciphering and modeling hydrochemical fluctuations and water-rock interaction in the upper crust and for retention mechanisms associated with underground repositories for toxic wastes. Metal scavenging into calcite has generally been established in the laboratory or in natural environments that cannot be unreservedly applied to conditions in deep crystalline rocks, an environment of broad interest for nuclear waste repositories. Here, we report a microanalytical study of calcite precipitated over a period of 17 years from anoxic, low-temperature $\left(14{ }^{\circ} \mathrm{C}\right)$, neutral ( $\mathrm{pH}: 7.4-7.7)$, and brackish (Cl: $1700-7100 \mathrm{mg} / \mathrm{L})$ groundwater flowing in fractures at 
$>400 \mathrm{~m}$ depth in granite rock. This enabled assessment of the trace metal uptake by calcite under these deep-seated conditions. Aquatic speciation modeling was carried out to assess influence of metal complexation on the partitioning into calcite. The resulting environmentspecific partition coefficients were for several divalent ions in line with values obtained in controlled laboratory experiments, whereas for several other ions they differed substantially. High absolute uptake of rare earth elements and U(IV) suggests that coprecipitation into calcite can be an important sink for these metals and analogousactinides in the vicinity of geological repositories.

\section{Introduction}

The trace element composition in calcite has been frequently used as a proxy to decipher (1) fluid sources and hydrochemical fluctuations in ore deposits(1) and tectonically active regions, $(2)(2)$ past climatic changes, $(3,4)$ and $(3)$ temperature and salinity variation in oceans. $(5,6)$ Uptake of toxic metals into calcite is also an important remediation process for contaminated $\operatorname{sites}(7)$ and therefore constitutes a growing interest at potential nuclear waste repository sites, $(8-10)$ where naturally occurring calcite in the bedrock fracture systems and newly precipitated calcite formed by various processes associated with disturbed conditions in the vicinity of the repository may offer important scavenging capacity of radionuclides along the flow paths.

The application and the reliability of the mentioned cases require knowledge of the partitioning of the dissolved metals into calcite. Numerous laboratory experiments in which metals $(\mathrm{Me})$ have co-precipitated with calcite have determined partition coefficients for a series of metals.(11) These coefficients are derived from dividing the ratio of the molar fractions of the specific metal $(\mathrm{Me})$ and $\mathrm{Ca}$ in calcite with the ratio of molar concentrations of $\mathrm{Me}$ and $\mathrm{Ca}$ of the solution. However, coefficients established in the laboratory, particularly for metals that are not structurally compatible with $\mathrm{Ca}^{2+}$, cannot indisputably be applied to natural conditions because of their non-thermodynamic phenomenological nature under a given set of conditions.(12) Therefore, phenomenological partition coefficients $\left(p_{\mathrm{Me}}\right)$ have to be determined and the existing thermodynamic descriptions need to be verified for different natural environments, either under controlled analogue conditions in the laboratory or directly in the field. Laboratory studies carried out for this purpose have typically been mimicking marine $(13,14)$ or $\operatorname{karst}(15,16)$ conditions.

Several countries are planning for deep geological disposal of nuclear waste in crystalline (granite) rock.(17) Mineral-metal $p_{\mathrm{Me}}$ 's specific to this environment are thus needed, primarily 
because they are relevant in models of radionuclide retention around the repositories. $(11,18)$ Of particular interest are radionuclides such as $\mathrm{Sr}, \mathrm{Cs}, \mathrm{U}$, and other actinides. Because several of the actinides do not exist in nature, elements such as certain rare earth elements (REE), which have similar properties as the trivalent actinides, can be used as natural analogues.(11) In addition, the REEs may also occur as radionuclides, e.g., ${ }^{151} \mathrm{Sm}$ and ${ }^{154} \mathrm{Eu}$. In the potential candidate areas for deep nuclear waste disposal in Sweden, Finland, and Canada, calcite is a major mineral along the flow paths in the fracture network.(19-22) Additionally, inflow and mixing of water, grouting of part of the repository tunnel walls during the construction phase, and hydrogeochemical evolution during different foreseen natural hydrological cycles (e.g., transgressions and deglaciations) are all expected to cause favorable conditions for the groundwater to reach supersaturation with respect to calcite. $(23,24)$ Further, metal coprecipitation with calcite is expected to be an important retention mechanism around cementitious repositories, such as for low- and intermediate-level radioactive waste.(11) The very few studies of trace-element abundance in young calcite from these settings (mainly Sweden) have shown only partial correspondence with the trace-element abundance in groundwater when using $p_{\mathrm{Me}}$ from the laboratory. $(8,9,25)$ This can be explained, at least partly, by a complex (unmatching) timing relationship, that is, the waters presently residing in the fractures may be much younger (Holocene in the upper $500 \mathrm{~m}$ ) than the calcite in the fractures (mainly preHolocene). There is thus a strong need to investigate trace element incorporation into calcite in situ during natural conditions in deep crystalline bedrock.

Here, we present a study where current groundwater and recently (within 17 years) precipitated calcite in boreholes in deep granitoid rock ( $>400 \mathrm{~m}$ below sea level) have been sampled and analyzed for trace-element compositions. This provided a rare possibility to determine the in situ metal uptake into calcite under reducing low-temperature $\left(14^{\circ} \mathrm{C}\right)$ and near-neutral $\mathrm{pH}(7.4-7.7)$ conditions in deep granitoid aquifers. The overall aim was to determine the environment specific partition coefficients of several cations, particularly those of interest for nuclear waste disposal, for modern calcite deep in crystalline bedrock.

\section{Materials and Methods}

\section{Site, Materials, and Sampling}

The studied boreholes (KA3105A at $415 \mathrm{~m}$ depth and KA3385A at $445 \mathrm{~m}$ depth, hereafter named A and B, respectively) were drilled in 1994-1995 in the Proterozoic granitoids of the Äspö Hard Rock Laboratory (HRL), SE Sweden, a full-scale test-facility tunnel built and operated by the Swedish Nuclear Fuel and Waste Management Co. (SKB) (Figure 1a,b). The boreholes, drilled 
horizontally into the tunnel wall, have lengths of 34 and $69 \mathrm{~m}$, respectively, and have been equipped with inflatable pairs of rubber packers, connected by rods of Al running through the whole length of the boreholes (Figure 1c,d). The packer system isolates (packed-off) borehole sections intersected by targeted individual or clusters of water conductive fractures from which water can be extracted from the tunnel wall through individual polyamide tubing for each section (three sections in A and one in B; Figure 1c). The tubing is fastened to the Al rod by black tape. Calcite crystals observed on the borehole instrumentation, after this was withdrawn in 2012, were scraped off for laboratory analysis. The groundwater in each packed-off section is composed of "stagnant water", which is sampled without pumping and may have been affected by the borehole instrumentation, and "fracture water" collected after discharge of 10 section volumes and thus is a true representation of the groundwater residing in the targeted fractures. Both of these water types were sampled for chemical analysis by SKB before extraction of the borehole instrumentation in 2012. Additionally, chemical data of fracture water, collected by SKB from the borehole sections in 1995 until 2012 were revisited, and includes several sampling occasions in $\mathrm{B}(n=21$ samples $)$ and a few sampling occasions in A $(n=2-4)$.

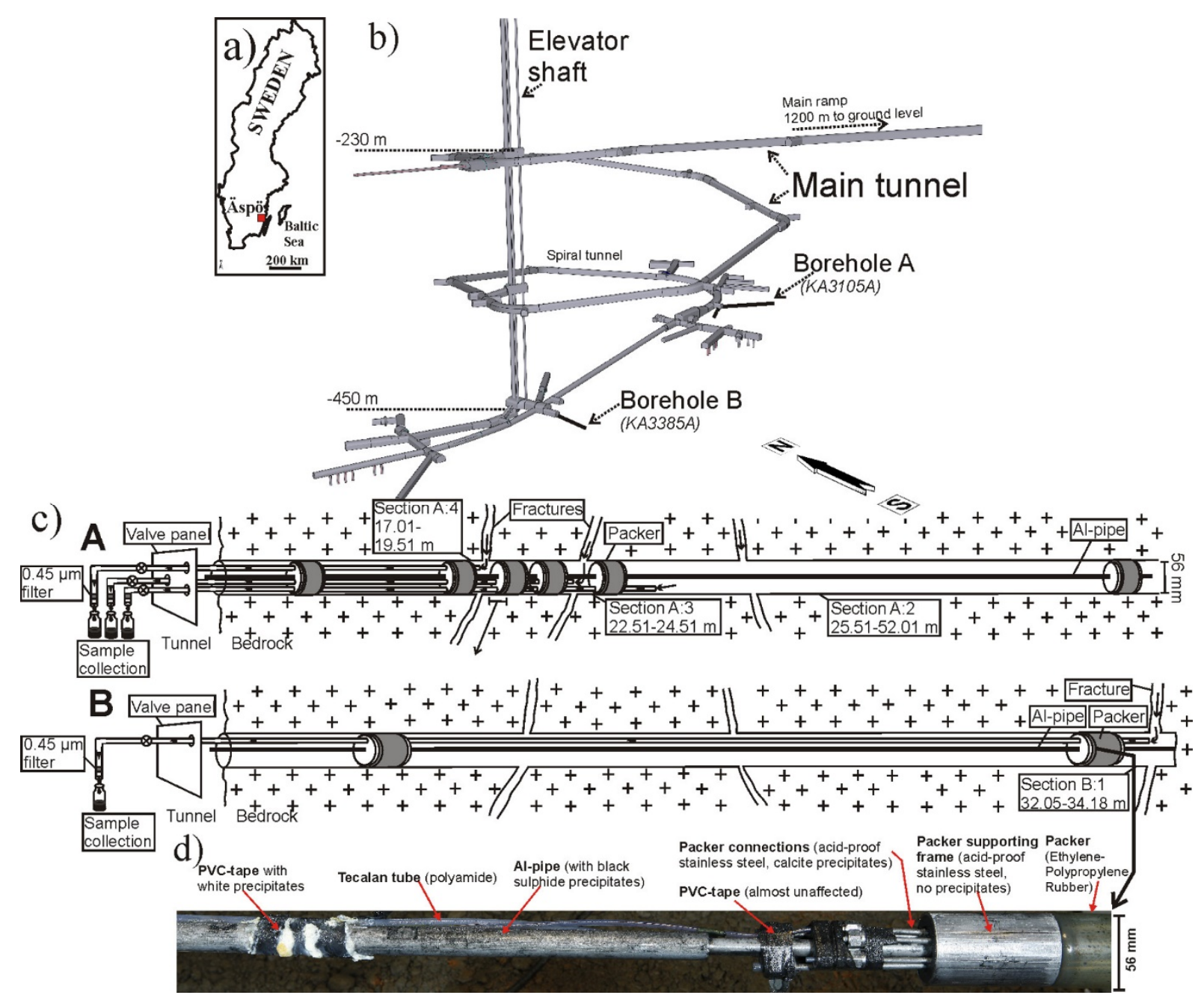


Figure 1. Site and materials. (a) Map of Sweden with Äspö Hard Rock Laboratory (HRL) indicated. (b) Underground layout of the Äspö HRL with the sampled boreholes marked. (c) Sketches of boreholes A and $B$ with sections for groundwater sampling and instrumentation indicated. The section volumes are A:2 65.2 L, A3 4.9 L, A:4 6.2 L, B:1 4.5 L, and the lengths indicated are the distance between each packed off section and the tunnel wall. (d) Photograph of the borehole instrumentation just after extraction of the instrumentation. Calcite had precipitated preferentially on the packer connections (but also on the Al-rod). Sulfide precipitates (black) were dominantly found on the Al-rod and Al-oxide precipitates were almost exclusively observed close to the PVC-tape. Modified from ref $\underline{29}$.

\section{Analysis}

The mineral material was first analyzed at low-vacuum mode on a Hitachi scanning electron microscope (SEM) equipped with an electron dispersive spectrometer (EDS) for identification of calcite crystal habits and cogenetic minerals. Calcite crystals were then hand-picked with tweezers under the stereo-microscope and split into two batches. One batch was analyzed with $X$-ray diffraction $(X R D)$ for identification of the carbonate mineral phases (method presented in the Supporting Information), and the other batch of crystals was mounted in epoxy and polished to expose cross sections of the crystals. The mounted crystals were analyzed with Raman spectroscopy (following published settings $(19)$ ) in order to confirm that no other minor carbonate phases, such as aragonite, occurred within the calcite crystals. Intracrystal zonations (overgrowths) of the polished calcite crystals were documented with SEM and then targeted using LA-ICP-MS (a NWR213 laser ablation system coupled to an Agilent 7500 quadropole ICPMS) with a spot size of 30 or $40 \mu \mathrm{m}$ (one session used $10 \times 40 \mu \mathrm{m}$ rectangular spots) in transects of up to five analyses/crystal in several different analytical sessions (total spots $n=$ 232, between 24 and 53 from each borehole section). For the sessions using 40 and $30 \mu \mathrm{m}$ spots a fluence of 6 and $6.9 \mathrm{~J} / \mathrm{cm}^{2}$, energy of 0.076 and $0.061 \mathrm{~mJ}$, and frequencies 10 and $5 \mathrm{~Hz}$ were used, respectively. The setup of determined elements varied between the sessions (e.g., $\mathrm{Na}$ and Li were not analyzed for borehole B). Normalization was to a NIST 612 standard $(26)$ measured at regular intervals. Data reduction was made with Glitter software, allowing avoidance of inclusions from the reduced data. The carbonate standard MACS-3 was used as a matrix-matched secondary standard, both as a pellet and as a nanopellet, prepared following a published method.(27)Accuracy and precision was better than $5 \%$ for most elements with exceptions in some sessions (Table S1). LA-ICP-MS trace element mapping was carried out for a selection of calcite crystals from section A:4, following a published method.(28)

The calcite was also analyzed for stable isotope composition, including $\delta^{13} \mathrm{C}$ and $\delta^{18} \mathrm{O}$ in bulk samples, as well as in situ $\delta^{13} \mathrm{C}$ microanalyses within the calcite crystals, following previously 
published methods.(19) These data were then compared to $\delta^{13} \mathrm{C}$ and $\delta^{18} \mathrm{O}$ in the dissolved $\mathrm{HCO}_{3}{ }^{-}$(previously presented(29)).

The chemical and isotopic composition of the water samples (1995-2012), analyzed by SKB or in external accredited laboratories, was extracted from SKB's quality controlled database Sicada. This data includes $\mathrm{pH}$, electric conductivity, major/minor anions, and cations (including REEs), dissolved organic carbon (DOC), HS-, and stable isotopes (Table S2, where methods are briefly presented). REE concentrations are frequently below the limit of detection in the Sicada database: only light REEs (LREEs) are above detection in samples determined after routine filtration (0.45 um), whereas middle and heavy REE (MREE and HREE) concentrations are reported only for a few passive filter samples.(30) Therefore, high-resolution ICP-MS analyses of stagnant and fracture water from borehole $A$ was carried out in order to obtain concentrations for MREEs and HREEs. These analyses were performed on water sampled in 2015, after reinstallation of the instrumentation and a period of no pumping (stagnant conditions), and also included Cs and U. These analyses were quality controlled by analyzing the standard SPS-SW1 (generally within $3 \%$ uncertainty) and a blank of $2 \% \mathrm{HNO}_{3}$.

\section{Aqueous Speciation Modeling}

Aqueous speciation was modeled with the geochemical code Windermere Humic Aqueous model (WHAM), which includes the module Humic lon-Binding Model VII (HIBM-

VII),(31) allowing (through discrete modeling) consideration of binding of free cations to colloidal ligands in addition to inorganic anions. The modeling was applied to characterize the colloidal phases, including humic substances, as described previously.(32) Inorganic colloids were estimated according to the degree of supersaturation of the groundwaters with respect to both $\mathrm{Fe}$ and Al solid phases, mostly occurring under the form of illite and smectite along the fracture walls and in the reduced groundwaters. $(33,34)$ The quantitative estimation of the simulated clay colloids was performed with the geochemical computer code PhreeqC v3.0(35) and the use of the Lawrence Livermore National Laboratory thermodynamic database.(36) The binding properties of colloidal clays were modeled with no specific binding sites but a fixed negative charge. Therefore, cations were bound nonspecifically to the clays and depended mainly on the values of exchange capacity and surface area of the mineral phase. Speciation of the dissolved phase was modeled for both the fracture and stagnant water.

\section{Results}

\section{Calcite}


The X-ray diffraction analyses confirmed that all of the carbonate occurring on the instrumentation was calcite (Figure S1), and the Raman spectroscopy in situ analyses showed no trace of other carbonate phases within the calcite crystals. Euhedral calcite crystals of mainly scalenohedral type (Figure 2a-c), but also less $c$-axis elongated (Figure $2 d$ ), with abundant zonations/overgrowths (Figure 2c,d) had precipitated together with pyrite, minor barite (Figure 2b), FeS, fluorite, silica, Fe oxides and a series of Al oxides/(oxy)hydroxides and Al-rich clay minerals. $(29)$ The Al minerals and the sulfides were preferentially precipitated on the Al rods and the calcite on the steel connections at the packers (Figure 1d). Calcite showed variable and more or less section-specific trace element concentrations (Figure S3). Overall range was (percentiles 10-90, $P_{10}-P_{90}$, in ppm): Li: 1.9-3.4, Na: 390-910, Mg: 620-2080, Mn: 2000-4830, Fe: 144-940, Sr: 720-1200, Ba: 8.3-21, La: 2.3-24, Y: 0.8-10.5, Cs: 0.01-0.10 and U: 0.3-28.9 (Table S3). 

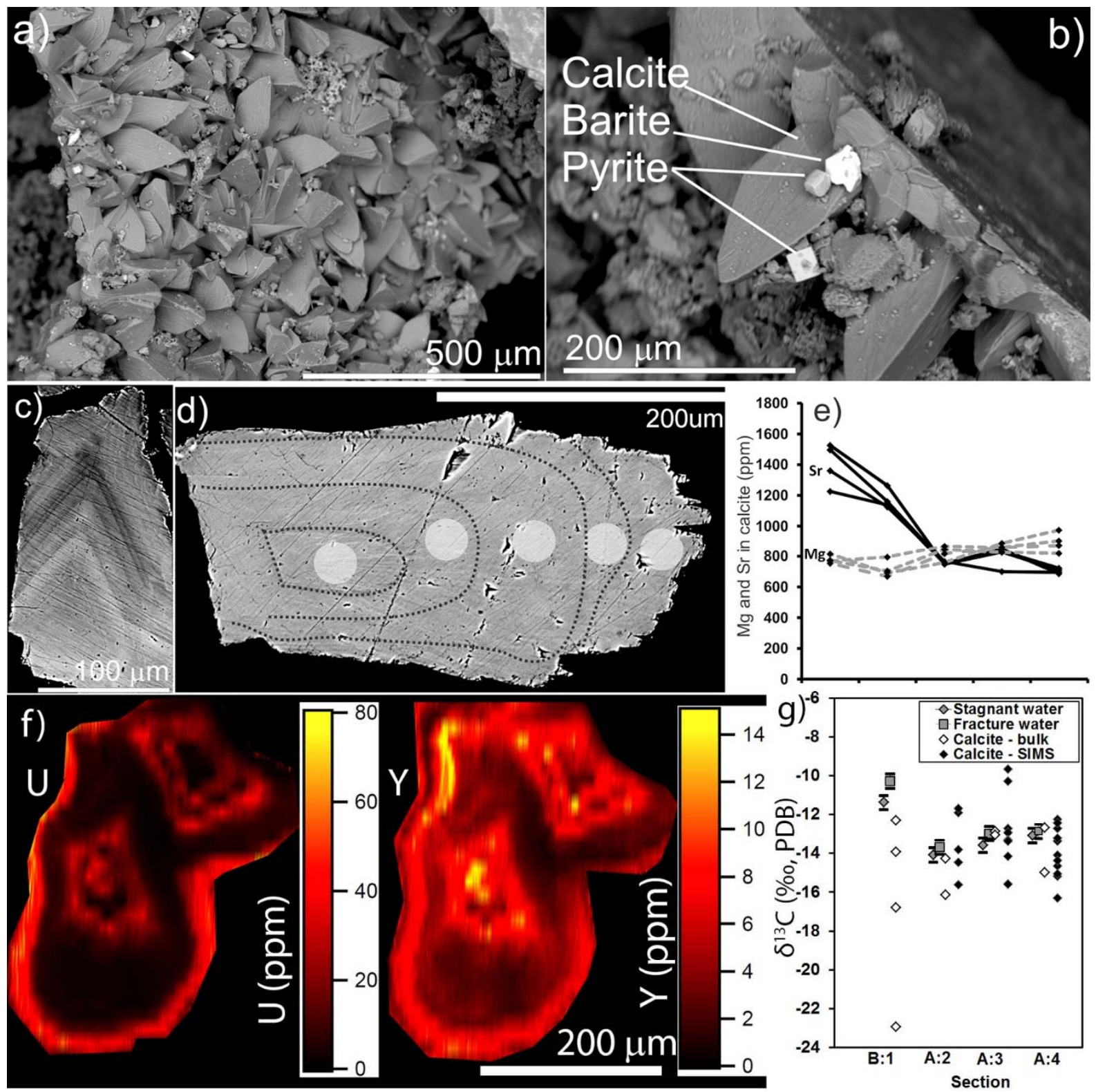

Figure 2. BSE-SEM images of calcite precipitates and chemical composition. (a) Precipitates dominated by euhedral calcite crystals in borehole B. (b) Close up of calcite and paragenetic pyrite and barite (from(29)). (c) Polished interior of a calcite crystal showing numerous growth zones (growth direction from bottom to top of image) in section A:3. (d) Polished interior of a calcite crystal showing five growth zones, from section A:2 (growth direction to the right). (e) Trace-metal chemistry transect of the spots indicated in "d" and in three other crystals from the same section for comparison. (f) Trace element ( $U$ and $Y$ ) distribution in a calcite crystal from section A:4. More examples are found in the Supporting Information. The maps have been masked to avoid the epoxy around the crystals. $(\mathrm{g}) \delta^{13} \mathrm{C}$ composition calculated for the fracture water (2012) and stagnant water (2012) and measured for the calcite (both bulk samples and in situ analyses).

For the waters, fractionation factors $(73)$ were used to calculate the hypothetical stable isotope composition of the water from which the calcite precipitated. A more detailed presentation of the stable isotope compositions is given in Figure S8. 


\section{Groundwater}

The fracture water in borehole A had relatively low concentrations of $\mathrm{Cl}^{-}(1700-2800 \mathrm{mg} / \mathrm{L})$ and $\mathrm{Ca}(350-610 \mathrm{mg} / \mathrm{L})$ and high concentrations of $\mathrm{HCO}_{3}{ }^{-}(120-230 \mathrm{mg} / \mathrm{L})$ and can be described as a slightly brackish $\mathrm{Na}-\mathrm{Ca} \mathrm{Cl}-\mathrm{SO}_{4}\left(\mathrm{HCO}_{3}\right)$ type. In contrast, the fracture water in $\mathrm{B}$ had high concentrations of $\mathrm{Cl}^{-}(6400-7100 \mathrm{mg} / \mathrm{L})$ and $\mathrm{Ca}(1750-2000 \mathrm{mg} / \mathrm{L})$ and low concentrations of $\mathrm{HCO}_{3}{ }^{-}(13-25 \mathrm{mg} / \mathrm{L})$ and can be described as a strongly brackish $\mathrm{Ca}-\mathrm{Na}(\mathrm{Mg}) \mathrm{Cl}-\mathrm{SO}_{4}$ type. Considerable concentration differences between the boreholes were also noticed for $\operatorname{Sr}(\mathrm{A}: 6-8$ mg/L, B: 40-44 mg/L), Li (A: 0.1-0.4 mg/L, B: 1.6-1.8 mg/L), and DOC (A: 5.0-7.5 mg/L, B: 1.0$1.5 \mathrm{mg} / \mathrm{L})$. By contrast, relatively small differences between the boreholes occurred for $\mathrm{Mg}$ (40$80 \mathrm{mg} / \mathrm{L}), \mathrm{Fe}(0.1-0.4 \mathrm{mg} / \mathrm{L})$, and $\mathrm{Mn}(0.3-0.7 \mathrm{mg} / \mathrm{L})$. Complete data are shown in Table S2. In borehole $\mathrm{A}$, the concentrations of $\mathrm{Cl}^{-}, \mathrm{Ca}, \mathrm{Na}, \mathrm{Sr}, \mathrm{Li}$, and $\mathrm{Ba}$ were lower in 2012 than at the start of the monitoring (1995), whereas in borehole B the concentrations of major ions were relatively stable throughout 1995-2012 (Figure S2). With respect to Ca, there were generally small variations of $\mathrm{Mg} / \mathrm{Ca}, \mathrm{Fe} / \mathrm{Ca}, \mathrm{Mn} / \mathrm{Ca}$, and $\mathrm{Sr} / \mathrm{Ca}$ with time (Table S2, Figure S2). Compared to the fracture water, the stagnant water had systematically higher $\mathrm{pH}$ and concentrations of $\mathrm{HS}^{-}$and $\mathrm{Al}$ and slightly higher Sr/Ca ratios (Figure S3f). Other metals showed variable and indecisive differences between stagnant and fracture waters (Figure S3).

\section{Partitioning between Calcite and Groundwater}

There was generally a correlation between the metal concentration in calcite and waters, e.g., lowest Mg and highest Sr occurred in borehole B water and calcite (Figure S4). The appearance of two other prominent features was important: first, for the calcite in section $A: 2$, there was a temporal evolution of decreasing Sr concentrations from 1500 to $700 \mathrm{ppm}$ (Figure 2e) and a similar trend for $\mathrm{Li}, \mathrm{Na}$, and $\mathrm{Ba}$ (Figure S5). Second, for the sections of borehole A, the number of calcite overgrowths correlated with the number of past water extractions (Figure S6). Because of these two features, the $p_{\mathrm{Me}}$ calculations were based on the outermost calcite overgrowths and the corresponding 2011-2012 hydrochemical data (2014-2015 for some elements). For borehole $B$, past water samplings were more frequent, and consequently, the crystals showed very finescaled zonation. Consequently, for this borehole the outermost zone alone could not be used for calcite-water comparison. This was, however, not of concern because this borehole showed insignificant hydrochemical variations over time. The LA-ICP-MS-mapping of crystals from section $A: 4$ showed that trace-element concentrations were variable among the growth zones but stable within the individual growth zones (Figure $2 f$, Figure S7). This confirms that the spot analyses used for $p_{\mathrm{Me}}$ calculations are representative for the entire growth zone. 
$p_{\mathrm{Me}}$ was calculated for each of the borehole sections for each metal above detection limit in the water and calcite. In order to avoid outliers in the relatively large calcite data set $(n=232)$, the $P_{10}-P_{90}$ molar concentrations [Me] of each metal were used. We calculated the maximum and minimum $p_{\text {Me }}$ by dividing the $P_{90}$ and $P_{10}$ ratio, respectively, of $[\mathrm{Me}] /[\mathrm{Ca}]_{\text {calcite }}$ with single $[\mathrm{Me}] /[\mathrm{Ca}]_{\text {solution }}$ values measured in the stagnant water and in the $\mathrm{A}: 2$ fracture water. For the fracture water in the other sections ( $B$ and $A: 3-A: 4)$, an interval instead of a single value was used for the calculation of minimum and maximum values; for $B$ in 1995-2012, and for A:3-A:4 in 2011-2012. The $p_{\mathrm{Me}}$ were for several metals, mainly major cations $(\mathrm{Fe}=0.64-7.0, \mathrm{Mg}=$ $0.017-0.049, \mathrm{Mn}=4.8-20.8, \mathrm{Na}=0.004-0.0010, \mathrm{Sr}=0.09-0.021)$, in line with published laboratory determinations, whereas those for the REEs (e.g., $p_{\mathrm{La}}=8.6-1420 ; p_{\mathrm{Yb}}=1.7-42$ ) and $Y$ (4.2-74.8) were significantly lower and for $\mathrm{Ba}(0.075-1.10)$, Cs (0.0010-0.65), U (1.8-150), and partly for Li (0.0061-0.022) were dominantly higher (Figure 3, Table S4). It should be noted that during all flushing events, stagnant water was replaced by pristine fracture water and that, consequently, it is not possible to tell whether a particular calcite growth zone precipitated from a "pure" stagnant or "pure" fracture water; instead, the water has evolved from fracture water to stagnant water due to within-section biogeochemical processes and mineral precipitation. 


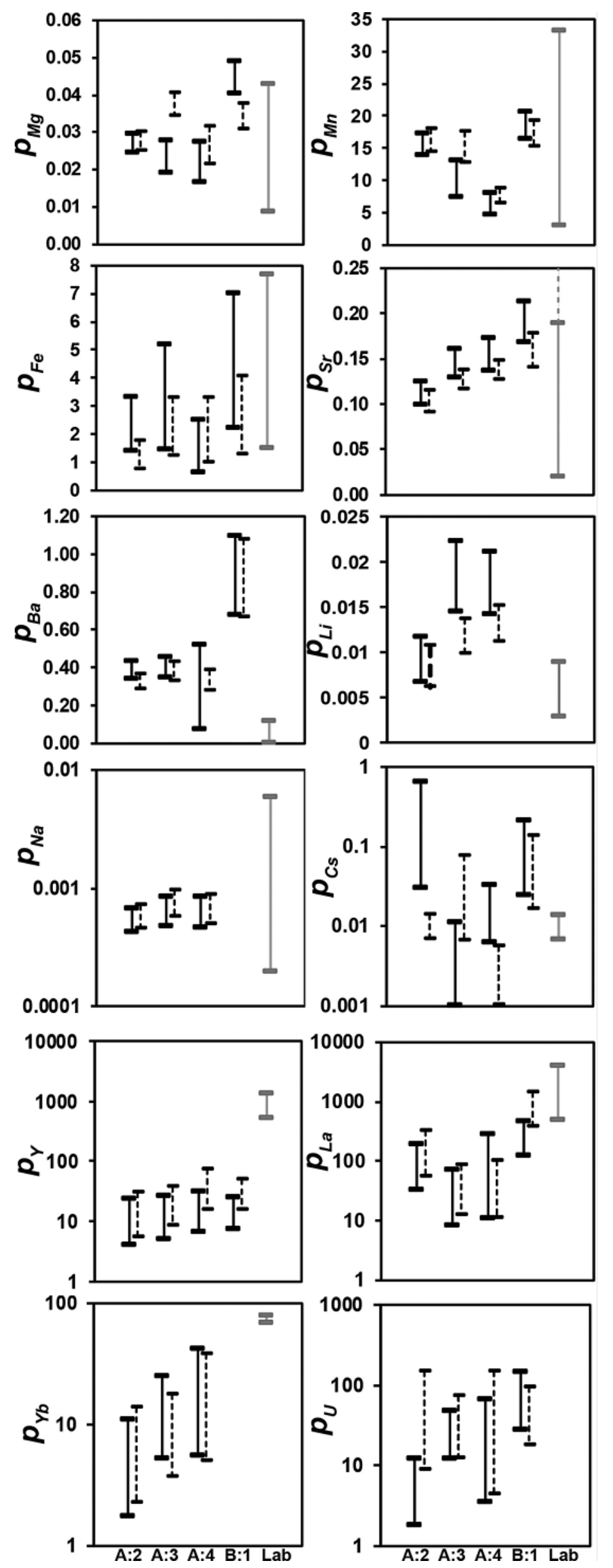


Figure 3. Ranges of partition coefficients $(p)$ calculated based on the calcite and groundwater data for borehole sections A:2, A:3, A:4, and B:1 (using the outermost calcite zone and latest hydrochemical data for borehole A) and reported in previous laboratory studies (references are listed in Table S4). The span was calculated from the $P_{10}-P_{90} \mathrm{Me} / \mathrm{Ca}$-molar fraction ratios of the calcite and the molar concentration ratios in the fracture groundwater (filled lines) and stagnant groundwater (stippled lines) in each section. For $p_{\mathrm{sr}}$, most experiments show values lower than 0.18 , except for a single experiment showing up to $0.4^{63}$ (indicated by the stippled line). It should be noted that the laboratory-derived coefficients for Cs are from sorption experiments and that one experiment under reducing conditions showed significantly higher coefficients (up to 0.44$)^{49}$. For $p u$ there are no literature values available for incorporation of U(IV). Note that log-scale is used for some metals.

The calcite had bulk $\delta^{18} \mathrm{O}$ values and partly also $\delta^{13} \mathrm{C}$ values that in general were in the range of those of the waters, when fractionation factors from the literature are applied and temporal variation of the waters considered (Figure 2g, Figure S8). However, the $\delta^{13} \mathrm{C}$ values were slightly lower in the stagnant water than the fracture water, and the calcite tended to be relatively light, especially in $\mathrm{B}: 1$. The $\delta^{13} \mathrm{C}$ of calcite from $\mathrm{A}$ showed intracrystal variation of up to $7 \%$ V-PDB but no general growth-related trend (Figure $2 \mathrm{~g}$ ).

\section{Aquatic Speciation Modeling}

The aquatic modeling suggested that most of the major cations, $\mathrm{Ba}$ and $\mathrm{Cs}$, were present as free cations in solution (Figure 4a), whereas the REEs (in particular the HREEs), Y, and U were to a large extent bound to humic substances (HS, Figure 4d). Iron existed in the structure of colloidal clays in relatively large proportions in some of the stagnant waters, but not in the fracture water (Figure 4a, Table S5). Other important ligands were carbonate binding up to $48 \%$ of the LREE (Figure $4 \mathrm{e}$ ), $17 \%$ of $\mathrm{Mn}$, and $13 \%$ of Fe (Figure $4 \mathrm{~b}$ ), chlorine binding up to $21 \%$ of the $\mathrm{Mn}$ and $8 \%$ of Fe (Figure $4 \mathrm{c}$ ), and sulfate binding up to $13 \%$ of the Ba. 

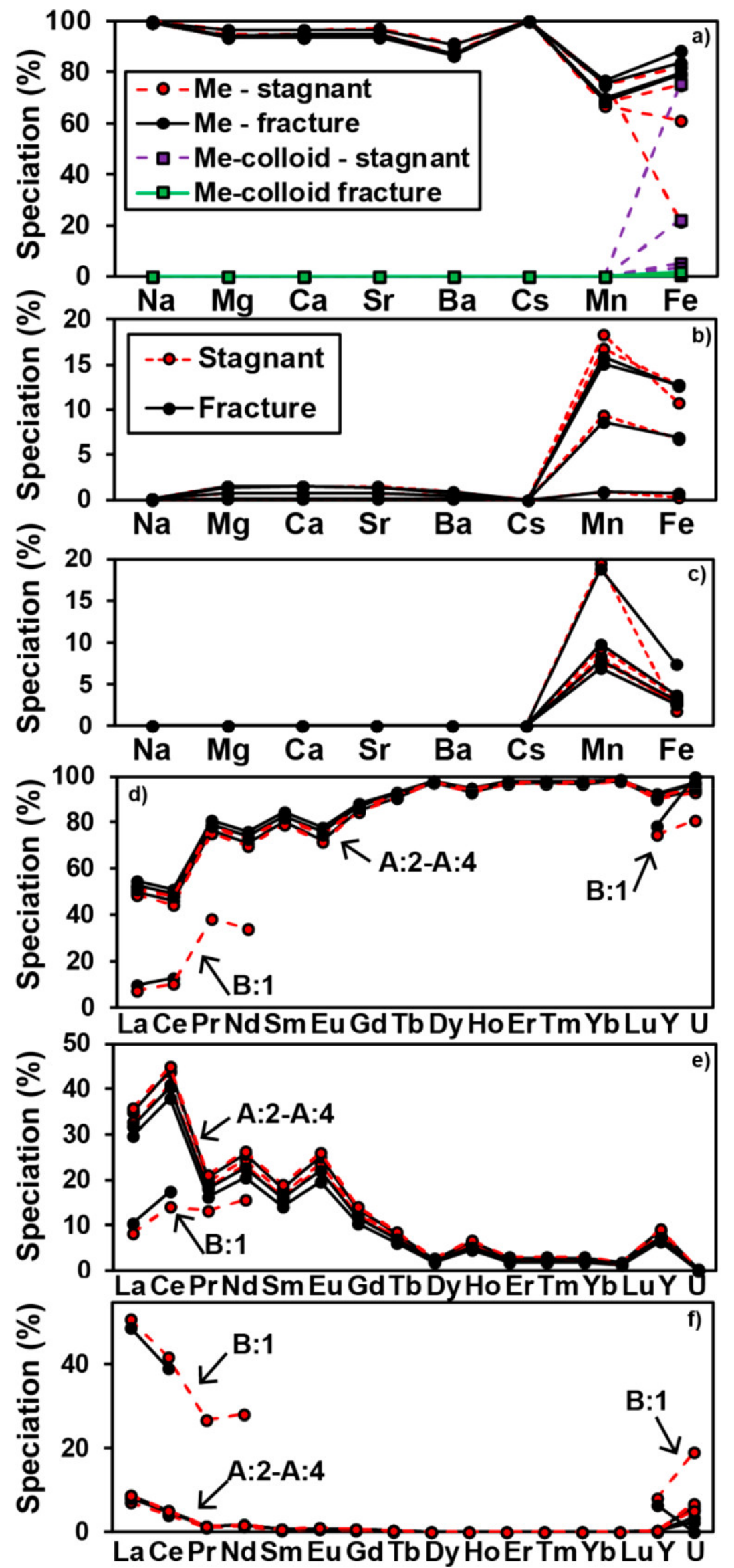
Figure 4. Speciation of metals in the water samples used for calculation of $p_{\text {Me }}$ (only showing complexes with over $15 \%$ contributions, see Tables S5 and S6 for full data). (a-C) Major cations Ba and Cs divided into (a) free metal ions and Me bound to organic colloids (almost exclusively affecting $\mathrm{Fe}$ in the stagnant water, especially in the high ionic strength B:1 waters with $75 \%$ colloid complexation, and A:2 with $22 \%$ ); (b) Carbonate complexes (including $\mathrm{MeHCO}_{3}{ }^{+}$and $\mathrm{MeCO}_{3}$ ), mainly affecting $\mathrm{Mn}$ and $\mathrm{Fe}$; the low binding is from $\mathrm{B}: 1$ where there are low $\mathrm{HCO}_{3}{ }^{-}$concentrations; (c) $\mathrm{Me}-\mathrm{Cl}$ complexes mainly affecting $\mathrm{Mn}$ and $\mathrm{Fe}$; the largest $\mathrm{Mn}-\mathrm{Cl}$ complexation is from section $\mathrm{B}: 1$ which has highest ionic strength. (d-f) $R E E+Y$ and $U$, with arrows indicating A:2-A:4 and B:1, respectively (speciation modeling was inhibited for MREE and HREE in $B: 1)$. These three diagrams show binding to (d) humic substances, (e) carbonate complexes representing the sum of $\mathrm{MeHCO}_{3}{ }^{+}, \mathrm{MeCO}_{3}$, and $\mathrm{Me}\left(\mathrm{CO}_{3}\right)^{2-}$, and (f) free cations. Note that the U-hydroxides are shown for $\mathrm{B}: 1$ instead of free cations for $\mathrm{U}$ (absent).

\section{Discussion}

\section{Calcite Growth and Stability}

The presence of sulfate-reducing bacteria (SRB) in biofilms on the borehole equipment and enhanced HS- concentrations and SRB cells in the stagnant water compared to the fracture water(37) show that bacterial sulfate reduction (BSR) has been an important process in the boreholes. Abundant formation of HS- has led to oversaturation and precipitation of sulfide after reaction with dissolved $\mathrm{Fe}^{2+}$. Additional evidence for $\mathrm{BSR}$ includes the highly variable S-isotope values of the sulfide precipitated on the borehole instrumentation $\left(\delta^{34} \mathrm{~S}:-47.2\right.$ to $+53.3 \%$ o CDT).(29) The BSR process also involves production of $\mathrm{HCO}_{3}^{-}$, which can react with dissolved $\mathrm{Ca}^{2+}$ in the water to form calcite. The $\delta^{13} C_{\text {calcite }}$ values are depleted but also highly variable (Figure $2 \mathrm{~g}$ ), pointing to local heterogeneity and potential also for precipitation that is not related to BSR, e.g., mixing of water types or corrosion processes causing supersaturation.(29)

The calcite crystals show growth zonation that matches the number of water extractions from the boreholes (Figure S6). Either these growth zones are related to a pressure drop during water sampling that has led to instant oversaturation and enhanced calcite growth, or alternatively, loosely attached microbial cells were flushed away during the water sampling, hampering the microbial activity (and thus calcite precipitation) in the boreholes until the biofilms had been reestablished. Significant equilibrium solid-state recrystallization from interaction with the groundwater, which in experiments has been shown to be fast in the outermost monolayers of calcite crystals,(38) has not occurred for the bulk of the studied calcite. The evidences are crystal growth zonations with distinct differences in trace element signatures (Figure 2f, Figure S7), and 
that the evolution in trace element chemistry across the growth zones can be related, such as in borehole A, to hydrochemical evolution in the fracture water (Figure 2e, Figures S3 and S5). The latter phenomenon is related to tunnel drawdown of Baltic seawater.(39)

\section{Incorporation of Metals into Calcite}

The structurally compatible divalent ions $\mathrm{Mg}, \mathrm{Mn}, \mathrm{Fe}$, and $\mathrm{Sr}$ (and $\mathrm{Ba}$ ) were predicted to occur in water, in a manner similar to that for $\mathrm{Ca}$, as dominantly dissolved free cations (Figure 4a). These cations $\left(\mathrm{Me}^{2+}\right)$ and $\mathrm{Ca}^{2+}$ are chemically similar, and the endmembers $\left(\mathrm{CaCO}_{3}\right.$, and $\left.\mathrm{MeCO}_{3}\right)$ have the same stoichiometry and structure (not given for $\mathrm{SrCO}_{3}$ for which a hypothetical endmember can be applied instead $(40,41))$. Complexation and ionic strength should therefore not affect the partitioning significantly, possibly with the exception of $\mathrm{Ba}^{2+}$, which is $30 \%$ larger than $\mathrm{Ca}^{2+}$ and forms $\mathrm{a} \mathrm{CO}_{3}$-phase that is not isostructural with calcite (see below). Consequently, there is generally a good agreement between the partitioning coefficient determined in this field study and those determined under controlled laboratory conditions for $\mathrm{Mn}, \mathrm{Mg}, \mathrm{Fe}$, and $\mathrm{Sr}$ (Figure 3). This feature, together with the overall similar partitioning for the stagnant and fracture waters, suggests that the uptake of these metals, which are not much involved in ongoing processes/interactions within the borehole sections, results from a fundamental fractionation. Hence, the empirical partition coefficients roughly coincide with the thermodynamic partition coefficients for these metals.

Although the incorporation of $\mathrm{Mg}, \mathrm{Mn}, \mathrm{Fe}$, and $\mathrm{Sr}$ generally coincides with laboratory-derived coefficients, it can be noted that the incorporation of $\mathrm{Sr}$ and $\mathrm{Mg}$ is in the upper range and $\mathrm{Mn}$ in the lower range, and that the minimum Fe uptake is relatively low (Figure 3, Table S4). The relatively high uptake for $\mathrm{Sr}$ and low for $\mathrm{Mn}$ may be partly explained by high precipitation rates in the boreholes. $(42,43)$ High precipitation rates lead to kinetic processes hampering $\mathrm{Mn}$ relative to $\mathrm{Sr}$ incorporation due to slow diffusion of the relatively large sized $\mathrm{Sr}^{2+}$ ion in the outermost monolayer during precipitation.(44) The aquatic modeling predicted significant Fe association with colloids in the stagnant water with highest ionic strength (B:1 77\% and $A: 222 \%$ ), whereas insignificant Fe-colloid association was predicted for the fracture water overall. The low $p_{\mathrm{Fe}}$ values of stagnant water in $\mathrm{B}: 1$ and $\mathrm{A}: 2$ can thus partly be explained by colloidal association (Figure 4a). However, colloids cannot be the sole explanation for the low $p_{\mathrm{Fe}}$ because low minimum $p_{\mathrm{Fe}}$ also occurs in sections with low degree of colloidal association. The Fe concentration in calcite and thus $p_{\mathrm{Fe}}$ varies extensively irrespective of aqueous speciation, which is proposed to be related to some degree to Fe sulfide formation following BSR in the stagnant water,(29) a common process in these fracture systems over geological time scales.(45) 
For $\mathrm{Ba}$, the relatively large ion size infers nonideal solid solution in the calcite structure and therefore the kinetic or entrapment effect is potentially strong, especially at high precipitation rates.(46-48) This can explain the much higher $p_{\mathrm{Ba}}$ in our natural samples (Figure 3 ) than in controlled experimental studies(49-51) working closer to equilibrium. Olsson et al.(52) explained similar high uptake in bulk travertine samples (precipitated from river water) by inclusion of barite, which is, however, not the case for our samples.

The monovalent cations $\mathrm{Li}, \mathrm{Na}$, and $\mathrm{Cs}$ have different charges than $\mathrm{Ca}^{2+}$, and therefore, incorporation is typically expected to be localized to dislocation sites. In contrast to the divalent cations described above, the lack of a relevant endmember phase inhibits determination of thermodynamic partition coefficients, and thus, empirical partition coefficients have to be obtained. Nevertheless, compared with the few existing experimental values, our empirical determinations fit well for $\mathrm{Na}$ and are only slightly higher for $\mathrm{Li}$ (Figure 3). This shows that the experimental values for these ions are generally valid under the natural conditions described here. For Cs, the values overlap but are in our data more scattered than results from batchsorption experiments (Figure 3).(53) Hu et al.(54) presented batch sorption of $\mathrm{Cs}^{+}$to carbonate rock under reducing conditions, i.e., similar to our conditions, and found values in line with our high-end values. Sodium and Cs were modeled to occur as dissolved monovalent ions in the solution (no speciation model database available for $\mathrm{Li}$ ), which means that complexation should not matter for these cations. A possible reason for the large variability in $p_{\mathrm{Cs}}$ ( 3 orders of magnitude) is the abundance and availability of frayed edge sites of illite, which can strongly influence the solid-liquid partitioning of Cs.(55)

The strictly reducing conditions prevailing in the borehole sections strongly favor $U(I V)$, in accordance with observations of abrupt decrease in dissolved $\mathrm{U}(\mathrm{VI})$ with increasing depth in the fracture system around the Äspö HRL.(56) XAFS-spectroscopy investigations have indicated that calcite offers a very stable structural environment for $\mathrm{U}(\mathrm{IV})$ as the $\mathrm{U}^{4+}$ ion substitutes in the $\mathrm{Ca}$ site which does not involve any significant disruption of the local structure.(57) Experimental incorporation into calcite has so far been focused on $\mathrm{U}(\mathrm{VI})$ (i.e., $\mathrm{UO}_{2^{2+}}$ ), which has shown very low uptake $\left(p_{\cup}<0.26\right) .(58,59)$ Here, we present, to the best of our knowledge, the first partition coefficient determinations for $\mathrm{U}(\mathrm{IV})$ in calcite. The results show that the uptake is very high $\left(p_{\mathrm{U}}=\right.$ 1.8-150, Figure 3, Table S4), suggesting that incorporation of $U$ into calcite is strongly favored under the reducing conditions prevailing in the borehole sections. The LA-ICP-MS mapping showed homogeneous distribution of $U$ within individual growth zones, which means that $U$ is incorporated into the crystal lattice and not occurring as discrete U-phase inclusions in the calcite. The fact that the speciation modeling predicted that most of the dissolved $U$ is complexed to HS is challenging, considering that this species in general decreases the uptake in 
calcite.(60) The temporal variability of the uptake $U$ and other metals (Figure $2 f$ ) is enigmatic but might be due to variation in solution $\mathrm{Me} / \mathrm{Ca}$ ratios, precipitation rate and speciation. It may possibly also be related to temporal variability of the available sites at different crystal surfaces during growth, which can affect $U$ uptake into calcite.(61)

The high incorporation of $\mathrm{U}$, and also of $\mathrm{Ba}$ and partly $\mathrm{Sr}$, hints that aragonite formation may have occurred as this phase incorporates these metals more readily than calcite. $(62,63)$ In addition, recrystallization of aragonite to calcite may preserve high $U$ concentrations in the calcite.(64) We can, however, reject aragonite formation or recrystallization to calcite as there is (1) no trace of aragonite neither in the XRD analyses (Figure S1) nor in the Raman spectroscopic spot analyses of the crystal interiors and (2) dominant scalenohedral habit of the crystals, which rules out pseudomorphic recrystallization after aragonite that typically consists of acicular crystals of the orthorhombic system.

Trivalent Eu and other trivalent ions (e.g., Am) may be structurally incorporated and replace $\mathrm{Ca}$ in the calcite lattice,(65-67) but thermodynamic considerations and spectroscopic results $(66,68$ 70)show that a range of incorporation species and potential endmember phases can be involved. Formulating thermodynamically meaningful partition coefficients is therefore challenging, and empirical partition coefficients that do not account for charge balance upon $\mathrm{Me}^{3+}$ exchange with $\mathrm{Ca}^{2+}$ are generally not applicable in a thermodynamic sense. It is therefore not unexpected that our empirical partition coefficients for the REEs and $Y$ do not match; i.e., they are much lower than results from laboratory experiments (Figure 3). The relatively low incorporation of REE and $\mathrm{Y}$ into calcite in our study can be due to a number of processes. First, the modeling predicted that approximately $10-50 \%$ of La and up to $90-95 \%$ for the HREEs and $Y$ in the groundwater was complexed with organic colloids (Figure $4 \mathrm{~d}$ ), which is likely to have reduced the extent of incorporation into calcite.(60) Second, the low dissolved REE concentrations in the groundwater may be important because experiments demonstrate positive correlation between REE concentrations and uptake.(13) Third, the relatively low ionic strength of the groundwaters in borehole A can be another significant parameter, because experiments show positive correlation between $\mathrm{REE}^{3+}$ partitioning and $\mathrm{Na}^{+}$concentration in solution due to coupled ion substitution such as $\mathrm{Na}^{+}+\mathrm{REE}-\left(\mathrm{CO}_{3}\right)^{+} \leftrightarrow \mathrm{Ca}^{2+}$ combined to surface migration, reorientation and dehydration.(13)Fourth, REE-carbonate complexation including $\mathrm{REE}\left(\mathrm{CO}_{3}\right)^{+}$and $\mathrm{REE}\left(\mathrm{CO}_{3}\right)_{2}^{-}$can matter because different relative partitioning into calcite depends on which carbonate complex dominated in the experimental solution,(71) which is relevant for the system studied here as the REEs in the groundwater show a systematic difference between the proportions of different carbonate complexes throughout the REE series (Tables S5 and S6). Significant influence of Alrich colloids can, in contrast, be ruled out as the proportion of REE-HS complexes decreased 
only a couple of percent in the stagnant water where Al was substantially elevated (Table S2). In order to explain the difference in LREE uptake between the two boreholes, mechanism (2) is likely to be significant.

\section{Sequestration Potential of Calcite}

Several metals showed empirical partition coefficients roughly coinciding with laboratory-derived coefficients, particularly the divalent ions but also some of the monovalent ions, whereas others showed significantly different uptake (e.g., REE and Ba). Discrepancies can be explained by the fact that for some of the metals thermodynamic coefficients are difficult or impossible to determine and that the uptake in the system studied here may be affected by a range of parameters such as metal concentrations, ionic strength, precipitation rates, and aqueous complexation that differ from laboratory determinations. Consequently, the results presented here improve the confidence level for metal uptake in calcite precipitated in fractures deep in crystalline bedrock (and elsewhere under similar conditions) and are thus relevant in terms of models of radionuclide retention around nuclear waste repositories. The studied system is slightly disturbed, which is, however, not a drawback, as such conditions will be expected in the vicinity of a nuclear waste repository, partly due to introduced materials and partly as a consequence of the excavation leading to intensified water mixing, draw-down of surficial water, upflow of deep groundwater,(39) and possibly changes in microbial activity. This knowledge is needed in studies of metal scavenging and fluid circulation in crystalline bedrock, in general, and for safety-assessment related retention models for nuclear waste repositories, in particular. Because both pristine fracture water and instrumentation-affected stagnant water were included, the partition-coefficient ranges obtained represent the entire capability of calcite to trap various dissolved metals in a deep system near a disposal.

The metal and isotopic compositions of natural calcite precipitated over hundreds of millions of years within the bedrock fractures in the same area as we have studied here are not in equilibrium with the current groundwater. $(19,72)$ This reflects a long-term nonequilibrium metastability in crystals over geologic time scales. This is in contrast to an experimental study by Heberling et al.(38) reporting a slow long-term recrystallization of the calcite. However, Heberling et al.(38) also report a fast initial recrystallization, which comprised only a few monolayers in smooth coarse crystals. This process may have occurred also in the natural calcite studied here, which overall is dominated by precipitation events. These features combined with high partitioning of many metals such as $\mathrm{U}(\mathrm{IV})$ and the actinide analogous REE:s (although lower than in laboratory experiments) in calcite suggest that this mineral has unique sequestration properties and can be a permanent sink for metals around a repository. 


\section{Acknowledgment}

We thank the Swedish Nuclear Fuel and Waste Management Co. for financial support and access to samples and data and D. Garbe-Schönberg for providing nanopellet standards. L. Alakangas and A.-S. Karlsson are thanked for water sampling and analysis. The insightful comments by F. Heberling and three anonymous reviewers greatly improved the paper. This is publication 538 of NordSIMS, a joint Swedish-Icelandic infrastructure.

\section{References}

This article references 73 other publications.

1.

Möller, P.; Morteani, G.; Hoefs, J.; Parekh, P. P. The origin of the ore-bearing solution in the Pb$\mathrm{Zn}$ veins of the western Harz, Germany, as deduced from rare-earth element and isotope distributions in calcites Chem. Geol. 1979, 26, 197- 215 DOI: 10.1016/0009-2541(79)90046-9

[Crossref]

2.

Uysal, I. T.; Feng, Y.-x.; Zhao, J.-x.; Bolhar, R.; Isik, V.; Baublys, K. A.; Yago, A.; Golding, S. D. Seismic cycles recorded in late Quaternary calcite veins: Geochronological, geochemical and microstructural evidence Earth Planet. Sci. Lett. 2011, 303, 84- 96 DOI:

10.1016/j.epsl.2010.12.039

[Crossref], [CAS]

3.

Bourdin, C. m.; Douville, E.; Genty, D. Alkaline-earth metal and rare-earth element incorporation control by ionic radius and growth rate on a stalagmite from the Chauvet Cave, Southeastern France Chem. Geol.2011, 290, 1-11 DOI: 10.1016/j.chemgeo.2011.08.006

[Crossref], [CAS]

4.

Fairchild, I. J.; Borsato, A.; Tooth, A. F.; Frisia, S.; Hawkesworth, C.

J.; Huang, Y.; McDermott, F.; Spiro, B.Controls on trace element (Sr-Mg) compositions of carbonate cave waters: implications for speleothem climatic records Chem.

Geol. 2000, 166, 255- 269 DOI: 10.1016/S0009-2541(99)00216-8

[Crossref], [CAS]

5. 
Eggins, S.; De Deckker, P.; Marshall, J. Mg/Ca variation in planktonic foraminifera tests: implications for reconstructing palaeo-seawater temperature and habitat migration Earth Planet. Sci. Lett. 2003, 212, 291-306 DOI: 10.1016/S0012-821X(03)00283-8

[Crossref], [CAS]

6.

Rosenthal, Y.; Boyle, E. A.; Slowey, N. Temperature control on the incorporation of magnesium, strontium, fluorine, and cadmium into benthic foraminiferal shells from Little Bahama Bank: Prospects for thermocline paleoceanography Geochim. Cosmochim.

Acta 1997, 61, 3633- 3643 DOI: 10.1016/S0016-7037(97)00181-6

[Crossref], [CAS]

7.

Tobin, K. J.; Colwell, F. S.; Onstott, T. C.; Smith, R. Recent calcite spar in an aquifer waste plume: a possible example of contamination driven calcite precipitation Chem.

Geol. 2000, 169, 449- 460 DOI: 10.1016/S0009-2541(00)00220-5

[Crossref], [CAS]

8.

Drake, H.; Heim, C.; Hogmalm, K. J.; Hansen, B. T. Fracture zone-scale variation of trace elements and stable isotopes in calcite in a crystalline rock setting Appl.

Geochem. 2014, 40, 11- 24 DOI: 10.1016/j.apgeochem.2013.10.008

[Crossref], [CAS]

9.

Drake, H.; Tullborg, E.-L.; Hogmalm, K. J.; Åström, M. E. Trace metal distribution and isotope variations in low-temperature calcite and groundwater in granitoid fractures down to $1 \mathrm{~km}$ depth Geochim. Cosmochim. Acta 2012, 84, 217- 238 DOI: 10.1016/j.gca.2012.01.039

[Crossref], [CAS]

10.

Denniston, R. F.; Shearer, C. K.; Layne, G. D.; Vaniman, D. T. SIMS analyses of minor and trace element distributions in fracture calcite from Yucca Mountain, Nevada, USA Geochim.

Cosmochim. Acta 1997, 61,1803-1818 DOI: 10.1016/S0016-7037(97)00049-5

[Crossref], [CAS]

11.

Curti, E. Coprecipitation of radionuclides with calcite: estimation of partition coefficients based on a review of laboratory investigations and geochemical data Appl.

Geochem. 1999, 14, 433- 445 DOI: 10.1016/S0883-2927(98)00065-1

[Crossref], [CAS]

12. 
Morse, J. W.; Bender, M. L. Partition coefficients in calcite; examination of factors influencing the validity of experimental results and their application to natural systems Chem.

Geol. 1990, 82, 265- 277 DOI: 10.1016/0009-2541(90)90085-L

[Crossref], [CAS]

13.

Zhong, S.; Mucci, A. Partitioning of rare earth elements (REEs) between calcite and seawater solutions at $25^{\circ} \mathrm{C}$ and $1 \mathrm{~atm}$, and high dissolved REE concentrations Geochim. Cosmochim.

Acta 1995, 59, 443- 453DOI: 10.1016/0016-7037(94)00381-U

[Crossref], [CAS]

14.

Mucci, A. Manganese uptake during calcite precipitation from seawater: Conditions leading to the formation of a pseudokutnahorite Geochim. Cosmochim. Acta 1988, 52, 1859- 1868 DOI:

10.1016/0016-7037(88)90009-9

[Crossref], [CAS]

15.

Huang, Y.; Fairchild, I. J. Partitioning of $\mathrm{Sr}^{2+}$ and $\mathrm{Mg}^{2+}$ into calcite under karst-analogue experimental conditions Geochim. Cosmochim. Acta 2001, 65, 47-62 DOI: 10.1016/S00167037(00)00513-5

[Crossref], [CAS]

16.

Day, C. C.; Henderson, G. M. Controls on trace-element partitioning in cave-analogue calcite Geochim. Cosmochim. Acta 2013, 120, 612-627 DOI: 10.1016/j.gca.2013.05.044

[Crossref], [CAS]

17.

Andersson, J.; Skagius, K.; Winberg, A.; Lindborg, T.; Ström, A. Site-descriptive modelling for a final repository for spent nuclear fuel in Sweden Environ. Earth Sci. 2013, 69, 1045- 1060 DOI: 10.1007/s12665-013-2226-1

[Crossref], [CAS]

18.

Piqué, À.; Arcos, D.; Grandia, F.; Molinero, J.; Duro, L.; Berglund, S. Conceptual and Numerical Modeling of Radionuclide Transport and Retention in Near-Surface

Systems Ambio 2013, 42, 476- 487 DOI: 10.1007/s13280-013-0399-1

[Crossref], [PubMed], [CAS]

19.

Drake, H.; Åström, M. E.; Heim, C.; Broman, C.; Åström, J.; Whitehouse, M.

J.; Ivarsson, M.; Siljeström, S.;Sjövall, P. Extreme ${ }^{13} \mathrm{C}$-depletion of carbonates formed during 
oxidation of biogenic methane in fractured granite Nat. Commun. 2015, 6, 7020 DOI:

10.1038/ncomms 8020

[Crossref], [PubMed], [CAS]

20.

Sandström, B.; Tullborg, E.-L. Episodic fluid migration in the Fennoscandian Shield recorded by stable isotopes, rare earth elements and fluid inclusions in fracture minerals at Forsmark, Sweden Chem. Geol.2009, 266, 126- 142 DOI: 10.1016/j.chemgeo.2009.04.019

[Crossref]

21.

Sahlstedt, E.; Karhu, J. A.; Pitkänen, P. Indications for the past redox environments in deep groundwaters from the isotopic composition of carbon and oxygen in fracture calcite, Olkiluoto, SW Finland Isot. Environ. Health Stud. 2010, 46, 370- 391 DOI:

10.1080/10256016.2010.505981

[Crossref], [PubMed], [CAS]

22.

Frape, S. K.; Blyth, A. R.; Jones, M. G.; Blomqvist, R.; Tullborg, E. L.; McNutt, R.

$\mathrm{H}$.; McDermott, F.; Ivanovich, M., A comparison of calcite fracture mineralogy and geochemistry for the Canadian and Fennoscandian shields. In Proceedings of the 7th International Symposium on Water-Rock Interaction;Kharaka, Y. K.; Maest, A. S., Eds.; A.A. Balkema: Park City, UT, 1992; pp 787-791.

23.

Gimeno, M. J.; Auqué, L. F.; Acero, P.; Gómez, J. B. Hydrogeochemical characterisation and modelling of groundwaters in a potential geological repository for spent nuclear fuel in crystalline rocks (Laxemar, Sweden) Appl. Geochem. 2014, 45, 50- 71 DOI:

10.1016/j.apgeochem.2014.03.003

[Crossref], [CAS]

24.

Gómez, J. B.; Gimeno, M. J.; Auqué, L. F.; Acero, P. Characterisation and modelling of mixing processes in groundwaters of a potential geological repository for nuclear wastes in crystalline rocks of Sweden Sci. Total Environ. 2014, 468-469, 791- 803 DOI:

10.1016/j.scitotenv.2013.09.007

[Crossref], [PubMed], [CAS]

25.

Maskenskaya, O. M.; Drake, H. D.; Mathurin, F. E.; Åström, M. E. The role of carbonate complexes and crystal habit on rare earth element uptake in low-temperature calcite in fractured crystalline rock Chem. Geol. 2015, 391, 100- 110 DOI: 10.1016/j.chemgeo.2014.10.030

[Crossref], [CAS]

26. 
Jochum, K. P.; Scholz, D.; Stoll, B.; Weis, U.; Wilson, S.

A.; Yang, Q.; Schwalb, A.; Börner, N.; Jacob, D. E.;Andreae, M. O. Accurate trace element analysis of speleothems and biogenic calcium carbonates by LA-ICP-MS Chem.

Geol. 2012, 318-319, 31-44 DOI: 10.1016/j.chemgeo.2012.05.009

[Crossref], [CAS]

27.

Garbe-Schönberg, D.; Müller, S. Nano-particulate pressed powder tablets for LA-ICP-MS J. Anal. At. Spectrom. 2014, 29, 990- 1000 DOI: 10.1039/C4JA00007B

[Crossref]

28.

Roberts, N. W.; Walker, R. J. U-Pb geochronology of calcite mineralized faults; absolute dating of rift-related fault events on the northeast Atlantic margin Geology 2016, 44, 531- 534 DOI:

10.1130/G37868.1

[Crossref], [CAS]

29.

Drake, H.; Tullborg, E.-L.; Sandberg, B.; Blomfeldt, T.; Åström, M. E. Extreme fractionation and micro-scale variation of sulphur isotopes during bacterial sulphate reduction in Deep groundwater systems Geochim. Cosmochim. Acta 2015, 161, 1- 18 DOI: 10.1016/j.gca.2015.04.014

[Crossref], [CAS]

30.

Alakangas, L. J.; Mathurin, F. A.; Faarinen, M.; Wallin, B.; Åström, M. E. Sampling and Characterizing Rare Earth Elements in Groundwater in Deep-Lying Fractures in Granitoids Under In Situ High-Pressure and Low-Redox Conditions Aquat. Geochem. 2014, 20, 405- 418 DOI: $10.1007 / \mathrm{s} 10498-014-9225-\mathrm{z}$

[Crossref], [CAS]

31.

Tipping, E.; Lofts, S.; Sonke, J. E. Humic lon-Binding Model VII: a revised parameterisation of cation-binding by humic substances Environ. Chem. 2011, 8, 225- 235 DOI: 10.1071/EN11016

[Crossref], [CAS]

32.

Mathurin, F. A.; Åström, M. E.; Drake, H. D.; Maskenskaya, O. M.; Kalinowski, B. E. REE and Y in groundwater in the upper $1.2 \mathrm{~km}$ of Proterozoic granitoids (Eastern Sweden) - Assessing the role of composition and origin of groundwaters, geochemistry of fractures, and organic/inorganic aqueous complexation Geochim. Cosmochim. Acta 2014, 144, 342- 378 DOI:

10.1016/j.gca.2014.08.004

[Crossref], [CAS]

33. 
Nilsson, A. C.; Hedqvist, I.; Degueldre, C. Granitic groundwater colloids sampling and characterisation: the strategy for artefact elimination Anal. Bioanal.

Chem. 2008, 391, 1327- 1333 DOI: 10.1007/s00216-007-1782-1

[Crossref], [PubMed], [CAS]

34.

Hallbeck, L.; Pedersen, K. Explorative analyses of microbes, colloids, and gases together with microbial modelling. Site description model; SDM-Site Laxemar SKB Report R-08-109; Swedish Nuclear Fuel and Waste Management Co.: Stockholm, Sweden, 2009.

35.

Parkhurst, D. L. In Description of input and examples for PHREEQC version 3--a computer program for speciation, batch-reaction, one-dimensional transport, and inverse geochemical calculations. Appelo, C. A. J., Ed.; USGS, 2013.

36.

Bethke, C. M.; Yeakel, S. Geochemist's Workbench Users Guide, Version 10.0; Aqueous Solutions LCC:Champaign, 2014.

37.

Drake, H.; Hallbeck, L.; Pedersen, K.; Rosdahl, A.; Tullborg, E.-

L.; Wallin, B.; Sandberg, B.; Blomfeldt, T.Investigation of sulphide production in core-drilled boreholes in Äspö Hard Rock Laboratory. Boreholes KA3110A, KA3385A and

KA3105A; Swedish Nuclear Fuel and Waste Management Co., 2013.

38.

Heberling, F.; Paulig, L.; Nie, Z.; Schild, D.; Finck, N. Morphology Controls on Calcite

RecrystallizationEnviron. Sci. Technol. 2016, 50, 11735- 11741 DOI: 10.1021/acs.est.6b04011

[ACS Full Text $\bullet$ ], [CAS]

39.

Mathurin, F. A.; Åström, M. E.; Laaksoharju, M.; Kalinowski, B. E.; Tullborg, E.-L. Effect of Tunnel Excavation on Source and Mixing of Groundwater in a Coastal Granitoidic Fracture Network Environ. Sci. Technol. 2012, 46, 12779- 12786 DOI: 10.1021/es301722b

[ACS Full Text $\odot$ ], [CAS]

40.

Kulik, D. A.; Vinograd, V. L.; Paulsen, N.; Winkler, B. (Ca,Sr)CO3 aqueous-solid solution systems: From atomistic simulations to thermodynamic modelling Physics and Chemistry of the Earth, Parts A/B/C 2010, 35(6) 217- 232 DOI: 10.1016/j.pce.2010.04.011

[Crossref]

41.

Astilleros, J. M.; Pina, C. M.; Fernández-Díaz, L.; Putnis, A. Metastable phenomena on calcite $\{101 \overline{4}\}$ surfaces growing from $\mathrm{Sr} 2+-\mathrm{Ca} 2+-\mathrm{CO} 32-$ aqueous solutions Chem.

Geol. 2003, 193 (1) 93- 107 DOI: 10.1016/S0009-2541(02)00228-0 
42.

Tang, J.; Köhler, S. J.; Dietzel, M. Sr${ }^{2+} / \mathrm{Ca}^{2+}$ and ${ }^{44} \mathrm{Ca} /{ }^{40} \mathrm{Ca}$ fractionation during inorganic calcite formation: I. Sr incorporation Geochim. Cosmochim. Acta 2008, 72, 3718- 3732 DOI:

10.1016/j.gca.2008.05.031

[Crossref], [CAS]

43.

Pingitore, N. E., Jr.; Eastman, M. P. The coprecipitation of $\mathrm{Sr}^{2+}$ with calcite at $25^{\circ} \mathrm{C}$ and 1 atm Geochim. Cosmochim. Acta 1986, 50, 2195- 2203 DOI: 10.1016/0016-7037(86)90074-8

[Crossref], [CAS]

44.

Watson, E. B. A conceptual model for near-surface kinetic controls on the trace-element and stable isotope composition of abiogenic calcite crystals Geochim. Cosmochim.

Acta 2004, 68, 1473- 1488 DOI: 10.1016/j.gca.2003.10.003

[Crossref], [CAS]

45.

Drake, H.; Åström, M.; Tullborg, E.-L.; Whitehouse, M. J.; Fallick, A. E. Variability of sulphur isotope ratios in pyrite and dissolved sulphate in granitoid fractures down to $1 \mathrm{~km}$ depth evidence for widespread activity of sulphur reducing bacteria Geochim. Cosmochim.

Acta 2013, 102, 143- 161 DOI: 10.1016/j.gca.2012.10.036

[Crossref], [CAS]

46.

Thien, B. M. J.; Kulik, D. A.; Curti, E. A unified approach to model uptake kinetics of trace elements in complex aqueous - solid solution systems Appl. Geochem. 2014, 41, 135- 150 DOI: 10.1016/j.apgeochem.2013.12.002

[Crossref], [CAS]

47.

Heberling, F.; Vinograd, V. L.; Polly, R.; Gale, J.

D.; Heck, S.; Rothe, J.; Bosbach, D.; Geckeis, H.;Winkler, B. A thermodynamic

adsorption/entrapment model for selenium(IV) coprecipitation with calciteGeochim. Cosmochim.

Acta 2014, 134, 16- 38 DOI: 10.1016/j.gca.2014.02.044

[Crossref], [CAS]

48.

Shtukenberg, A. G.; Punin, Y. O.; Azimov, P. Crystallization kinetics in binary solid solutionaqueous solution systems Am. J. Sci. 2006, 306, 553- 574 DOI: 10.2475/07.2006.03

[Crossref], [CAS]

49. 
Tesoriero, A. J.; Pankow, J. F. Solid solution partitioning of $\mathrm{Sr}^{2+}, \mathrm{Ba}^{2+}$, and $\mathrm{Cd}^{2+}$ to calcite Geochim. Cosmochim. Acta 1996, 60, 1053- 1063 DOI: 10.1016/0016-7037(95)00449-1

[Crossref], [CAS]

50.

Pingitore, N. E.; Eastman, M. P. The experimental partitioning of $\mathrm{Ba}^{2+}$ into calcite Chem.

Geol. 1984, 45,113-120 DOI: 10.1016/0009-2541(84)90118-9

[Crossref], [CAS]

51.

Terakado, Y.; Taniguchi, M. A new method for the study of trace element partitioning between calcium carbonate and aqueous solution: $\mathrm{A}$ test case for $\mathrm{Sr}$ and $\mathrm{Ba}$ incorporation into calcite Geochem. J. 2006, 40,161- 170 DOI: 10.2343/geochemj.40.161

[Crossref], [CAS]

52.

Olsson, J.; Stipp, S. L. S.; Makovicky, E.; Gislason, S. R. Metal scavenging by calcium carbonate at the Eyjafjallajökull volcano: A carbon capture and storage analogue Chem.

Geol. 2014, 384, 135- 148 DOI: 10.1016/j.chemgeo.2014.06.025

[Crossref], [CAS]

53.

Borg, I. Y.; Stone, R.; Levy, H. B.; Ramspott, L. D. Information pertinent to the migration of radionuclides in ground water at the Nevada Test Site. Part 1. Review and analysis of existing information; US Energy Research \& Development, 1976.

54.

Hu, Q. H.; Zavarin, M.; Rose, T. P. Effect of reducing groundwater on the retardation of redoxsensitive radionuclides Geochem. Trans. 2008, 9, 12-12 DOI: 10.1186/1467-4866-9-12

[Crossref], [PubMed], [CAS]

55.

Mathurin, F. A.; Drake, H.; Tullborg, E.-L.; Berger, T.; Peltola, P.; Kalinowski, B. E.; Åström, M. E. High cesium concentrations in groundwater in the upper $1.2 \mathrm{~km}$ of fractured crystalline rock Influence of groundwater origin and secondary minerals Geochim. Cosmochim.

Acta 2014, 132, 187- 213 DOI: 10.1016/j.gca.2014.02.001

[Crossref], [CAS]

56.

Tullborg, E.-L.; Smellie, J.; Mackenzie, A. B. The use of natural uranium decay series studies in support of understanding redox conditions at potential radioactive waste disposal sites MRS Online Proc. Libr. 2003,807, 571- 576 DOI: 10.1557/PROC-807-571

[Crossref] 
57.

Sturchio, N. C.; Antonio, M. R.; Soderholm, L.; Sutton, S. R.; Brannon, J. C. Tetravalent Uranium in CalciteScience 1998, 281, 971 DOI: 10.1126/science.281.5379.971

[Crossref], [PubMed], [CAS]

58.

Meece, D. E.; Benninger, L. K. The coprecipitation of $\mathrm{Pu}$ and other radionuclides with

$\mathrm{CaCO}_{3}$ Geochim. Cosmochim. Acta 1993, 57, 1447- 1458 DOI: 10.1016/0016-7037(93)90005-H

[Crossref], [CAS]

59.

Kitano, Y.; Oomori, T. The coprecipitation of uranium with calcium carbonate J. Oceanogr. Soc. Jpn. 1971,27, 34- 42 DOI: 10.1007/BF02109313

[Crossref], [CAS]

60.

Kitano, Y.; Tokuyama, A.; Kanamori, N. Measurement of the distribution coefficient of zinc and copper between carbonate precipitate and solution J. Earth Sci., Nagoya Univ. 1968, 16, 58- 102

[CAS]

61.

Reeder, R. J.; Elzinga, E. J.; Tait, C. D.; Rector, K. D.; Donohoe, R. J.; Morris, D. E. Site-specific incorporation of uranyl carbonate species at the calcite surface Geochim. Cosmochim.

Acta 2004, 68,4799- 4808 DOI: 10.1016/j.gca.2004.05.031

[Crossref], [CAS]

62.

Wassenburg, J. A.; Scholz, D.; Jochum, K. P.; Cheng, H.; Oster, J.; Immenhauser, A.; Richter, D. K.;Häger, T.; Jamieson, R. A.; Baldini, J. U. L.; Hoffmann, D.; Breitenbach, S. F.

M. Determination of aragonite trace element distribution coefficients from speleothem calcitearagonite transitions Geochim. Cosmochim. Acta 2016, 190, 347- 367 DOI:

10.1016/j.gca.2016.06.036

[Crossref], [CAS]

63.

Reeder, R. J.; Nugent, M.; Lamble, G. M.; Tait, C. D.; Morris, D. E. Uranyl Incorporation into Calcite and Aragonite: XAFS and Luminescence Studies Environ. Sci.

Technol. 2000, 34, 638-644 DOI: 10.1021/es990981j

[ACS Full Text $\bullet$ ], [CAS]

64.

Domínguez-Villar, D.; Krklec, K.; Pelicon, P.; Fairchild, I. J.; Cheng, H.; Edwards, L.

R. Geochemistry of speleothems affected by aragonite to calcite recrystallization - Potential 
inheritance from the precursor mineral Geochim. Cosmochim. Acta 2017, 200, 310- 329 DOI: 10.1016/j.gca.2016.11.040

\section{[Crossref], [CAS]}

65.

Elzinga, E. J.; Reeder, R. J.; Withers, S. H.; Peale, R. E.; Mason, R. A.; Beck, K. M.; Hess, W. P. EXAFS study of rare-earth element coordination in calcite Geochim. Cosmochim.

Acta 2002, 66 (16) 2875-2885DOI: 10.1016/S0016-7037(02)00888-8

[Crossref], [CAS]

66.

\section{Marques}

Fernandes, M.; Schmidt, M.; Stumpf, T.; Walther, C.; Bosbach, D.; Klenze, R.; Fanghänel, T. Siteselective time-resolved laser fluorescence spectroscopy of Eu3+ in calcite J. Colloid Interface Sci. 2008, 321(2) 323-331 DOI: 10.1016/j.jcis.2008.01.017

[Crossref], [PubMed], [CAS]

67.

Stumpf, T.; Marques Fernandes, M.; Walther, C.; Dardenne, K.; Fanghänel, T. Structural characterization of Am incorporated into calcite: A TRLFS and EXAFS study J. Colloid Interface Sci. 2006, 302 (1) 240-245DOI: 10.1016/j.jcis.2006.06.010

[Crossref], [PubMed], [CAS]

68.

Curti, E.; Kulik, D. A.; Tits, J. Solid solutions of trace Eu(III) in calcite: Thermodynamic evaluation of experimental data over a wide range of $\mathrm{pH}$ and $\mathrm{pCO} 2$ Geochim. Cosmochim.

Acta 2005, 69 (7) 1721- 1737DOI: 10.1016/j.gca.2004.06.027

[Crossref], [CAS]

69.

Hofmann, S.; Voïtchovsky, K.; Schmidt, M.; Stumpf, T. Trace concentration - Huge impact: Nitrate in the calcite/Eu(III) system Geochim. Cosmochim. Acta 2014, 125, 528-538 DOI: 10.1016/j.gca.2013.10.008

[Crossref], [CAS]

70.

Hellebrandt, S. E.; Hofmann, S.; Jordan, N.; Barkleit, A.; Schmidt, M. Incorporation of Eu(III) into Calcite under Recrystallization conditions Sci. Rep. 2016, 6, 33137 DOI: 10.1038/srep33137

[Crossref], [PubMed], [CAS]

71.

Tanaka, K.; Ohta, A.; Kawabe, I. Experimental REE partitioning between calcite and aqueous solution at $25^{\circ} \mathrm{C}$ and $1 \mathrm{~atm}$ : Constraints on the incorporation of seawater REE into seamounttype limestonesGeochem. J. 2004, 38, 19-32 DOI: 10.2343/geochemj.38.19 
[Crossref], [CAS]

72.

Drake, H.; Heim, C.; Roberts, N. M.

W.; Zack, T.; Tillberg, M.; Broman, C.; Ivarsson, M.; Whitehouse, M. J.;Åström, M. E. Isotopic evidence for microbial production and consumption of methane in the upper continental crust throughout the Phanerozoic eon Earth Planet. Sci. Lett. 2017, 470, 108- 118 DOI:

10.1016/j.epsl.2017.04.034

[Crossref], [CAS]

73.

Emrich, K.; Ehhalt, D. H.; Vogel, J. C. Carbon isotope fractionation during the precipitation of calcium carbonate Earth Planet. Sci. Lett. 1970, 8 (5) 363- 371 DOI: 10.1016/0012$821 \times(70) 90109-3$

[Crossref], [CAS] 